\title{
Effect of Chloride-Contaminated Water on the Compressive Strength of Plain Concrete
}

\author{
${ }^{*}$ S. O. Ojoawo, ${ }^{+}$A.M. Oladejo \& ${ }^{+}$O. S Olaniyan \\ *Department of Civil Engineering, NMAM Institute of Technology, Nitte-574110, \\ Udupi District, Karnataka State, India \\ ${ }^{+}$Department of Civil Engineering, Ladoke Akintola University of Technology, \\ P.M.B 4000, Ogbomoso Nigeria \\ ${ }^{\#}$ Corresponding Author; Email: soojoawo@lautech.edu.ng
}

\begin{abstract}
:
The occurrence of pollution of water for mixing the other constituents of concrete has been on increase in saline areas this century. This research work investigates the effects of water contaminated with chloride salts on the compressive strength of concrete.

The mix ratio of 1:2:4 was employed for the concrete cubes (150mm $\times 150 \mathrm{~mm} \times 150 \mathrm{~mm})$, the batching of which was by volume. However, the distilled water for the concrete mix was polluted with varying concentrations of Sodium Chloride ( $\mathrm{NaCl}$ ) which ranges from Omg of the salt/litre of water (the control) to $500 \mathrm{mg}$ of salt/litre of water at an interval of 100mg/litre. After curing, the compressive strength tests were carried out on the concrete at 7 days, 28 days and 56 days.

Findings revealed that for Omg of salt/litre, the initial strength was retarded in the first 7days, uniformly progresses through 28 days until the $56^{\text {th }}$ day. For the contamination of 100mg/litre, the trend of concrete strength is similar to the control. As the quantity of contaminated salt increases after this stage, the compressive strength generally decreases. It was further observed that the contamination effects were not pronounced on the strength within the first 7 days. Fresh concrete with higher salt concentrations (exceeding $200 \mathrm{mg} /$ litre) however has elongated setting times. The respective 56-day compressive strengths found for the 0 , 100, 200, 300, 400 and 500mg of salt $/ \mathrm{l}$ of water were: $37.12,37.15,23.00,24.68,24.50,24.30 \mathrm{~N} / \mathrm{mm}^{2}$.

The study therefore concludes that the contamination effects of chloride salt on the compressive strength of concrete worsen with concrete age and thus should be prevented at all cost. The use of water free of impurities is hereby recommended in concrete mixing.
\end{abstract}

Keywords: Contamination, Chloride, Compressive Strength, Concrete, Solution

\section{Introduction}

Concrete is a composite material which consists of cement, fine aggregate (sand), coarse aggregate (gravel or crushed stone) and water. Its workability allows it to be easily used in many shapes. Concrete equally has very good compressive strength and resistance to fire [1], [2]. Concrete is basically of two types; dense concrete which is more common and with density of $24,000 \mathrm{~kg} / \mathrm{m}^{3}$ and the light weight concrete with density weighing less than $19,200 \mathrm{~kg} / \mathrm{m}^{3}$. Cement is a very important material in concrete. The commonly used one is the general normal setting Portland cement (the colour resembles Portland stone). The principal chemical compounds of Portland cements are; tricalcium silicate $\left(3 \mathrm{CaOS}_{1} \mathrm{O}_{2}\right)$, dicalcium silicate $\left(2 \mathrm{CaCOS}_{1} \mathrm{O}_{2}\right)$, tricalcium aluminate $\left(3 \mathrm{CaOAlO}_{3}\right)$ and tetracalcium alumino ferrite $\left(4 \mathrm{CaOAl}_{2} \mathrm{O}_{3} \quad \mathrm{Fe}_{2} \mathrm{O}_{3}\right)$, Shetty (2000). Contaminants/impurities are substances that concrete materials are exposed to, which affect the strength of either plain or reinforced concrete. Common contaminants include acids, chlorides, sulphates, organic matter e.t.c, [3]. The effect of chloride is of high concern and is the focus of this study.

Water is an important ingredient in concreting as it actively participates in the chemical reaction with cement. Its primary function in concrete mix is to start the hardening process of the concrete while its secondary function is to make the mix workable enough to satisfy the requirements of the job. The quality of water in concreting is however at stake when it is not free from oils, alkalis, acids, salts and other organic materials. The water to be used in mixing the concrete must be such that the chemical reactions which take place during the setting of the cement are not impaired. [1]. Also, water quality should be the one that would not inhibit corrosion to steel in reinforced concrete steel [4], [5].

The presence of chloride in cementitous materials can result in corrosion of embedded metallic materials [6]. In 1950s and 1960s in the United States of America, publications were presented on effect of chlorides on corrosion of concrete and recently ACI standardized limits on allowable chlorides in the constitutional materials which was put at $0.06 \%$ of the water-cement ratio or because different structure and their respective materials will have different chloride exposure and constituent. The sea water contains about 
$3.5 \%$ of salt where $78 \%$ is sodium chloride and $15 \%$ is chloride and sulphate of magnesium. It is generally discouraged to be used for reinforced as much as for mass concrete [6]. Corrosive effect of chloride contamination is an electrochemical process. When there is a difference in electrical potential along the steel reinforcement in concrete and electrical cell is set up, thereby forming ferric hydroxide due to the reaction between the water and the steel and converted by further oxidation to rust.

Chloride attack affects the durability of concrete. Previous research works examined the effects of concrete on the reinforced concrete [7], [8], [9], [10], [11] and concluded that guidance against chloride attack is particularly important because it primarily causes corrosion of reinforcement which is responsible for over 40 per cent of failure of structures. This present study however focuses on the effect of chloride-contaminated water on mass concrete. The objectives are to determine the strengths of concrete made with water of varying chloride contamination concentrations; to study the pattern of structural failures that may arise from chloride contamination; and to make appropriate recommendations based on the findings.

\section{Materials, Experimental Setup And Method}

The methods adopted in this research were field work and laboratory tests. The field work comprises of major processes in the preparation of concrete while the laboratory tests were conducted on the concrete materials and the hardened concrete.

\subsection{Sources of Materials and Type}

i. Cement: Ordinary Portland Cement, Lafarge (Elephant) cement brand which was obtained in bags of $50 \mathrm{~kg}$ sizes.

ii. Fine aggregate: sand of medium size and was obtained in tons from Julius Berger -dredged sand at Lekki, Lagos.

iii. Coarse aggregate: granite of three-quarter inch sizes obtained from the RCC Quarry along Lagos-Ibadan Express Way.

iv. Water: distilled water that has no taste (palatable), colour, odour or any impurity on one part for the control experiment; and the other part was chloride-contaminated.

v. Contaminants: The contaminants were Sodium Chloride $(\mathrm{NaCl})$ salt. This was in various concentrations of 0 , $100,200,300,400$ and $500 \mathrm{mg} / \mathrm{l}$ of water.

\subsection{Materials, tools and apparatus}

The tools and apparatus used for the research include weighing machine, measuring tape, set of British Standard sieves, specific density bottles, lubricating oil, head pans, shovels, hand trowels, $150 \mathrm{~mm}$ x $150 \mathrm{~mm}$ x $150 \mathrm{~mm}$ steel moulds, tapping rods, curing tank and the Compressive Strength Machine.

\subsection{Field work and Laboratory tests}

Field work included the following steps in the processes of preparing concrete:

(i) Lubricating oil was applied on the inner surfaces of the moulds in order to ensure smooth surfaced concrete cubes.

(ii) The Sieve analysis test was carried out in accordance to BS 4110:1986, to determine the particle size distribution of the aggregate sample. The sets of sieves were arranged in descending order of sieve sizes mounted on a sieve shaker which was operated mechanically (Plate 1 refers). The percentages of soil sample passing through each sieve were calculated as follows:

$\%$ passing $=\underline{\text { Total weight }- \text { weight retained }} \times 100 \%$

Total weight

While the percentage of sample retained can be calculated as follows:

$$
\% \text { retained }=\frac{\text { weight retained }}{\text { Total weight }} \times 100 \%
$$

Further analysis of cumulative percentage passing was calculated and the result was used to classify the soil. 


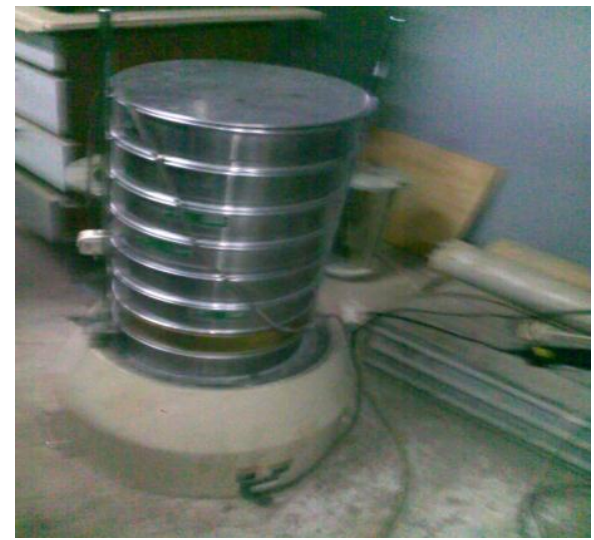

Plate 1: The set of Sieves employed in Particle Size Distribution Analysis

(iii) The specific gravity test was carried out to relate weights of the aggregates to their volume. The specific

gravity is the ratio of the weight in air of a given volume of particles to the weight in air of equal volume of distilled water at a stated temperature, usually $40^{\circ}$. A series of weighing was carried out after placing the soil in special density bottles.

Specific gravity, Gs was calculated thus:

Gs $=$ $\mathrm{W}_{2}-\mathrm{W}_{1}$

$$
\left(\mathrm{W}_{4}-\mathrm{W}_{1}\right)-\left(\mathrm{W}_{3}-\mathrm{W}_{2}\right)
$$

where

$\mathrm{W}_{1}=$ Weight of empty bottle

$\mathrm{W}_{2}=\quad$ Weight of bottle of dry soil only

$\mathrm{W}_{3}=\quad$ Weight of bottle + dry soil + water

$\mathrm{W}_{4}=\quad$ Weight of bottle + water only

(iv) Weighing was carried out during specific gravity test, sieve analysis and Compressive Strength test to determine the weight required for the respective tests to be carried out with the aid of weighing machine (as shown in Plate 2).

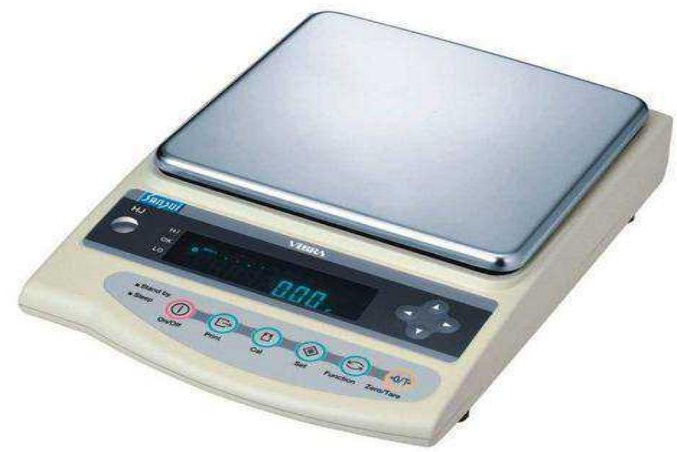

Plate 2: The weighing balance

(v) Batching was done by volume because of the small quantity of concrete operation that was involved. The mix ratio was 1:2:4 to achieve a grade 20 concrete. That is, 1 head pan of cement, 2 head pans of fine aggregate (sharp sand), and 4 head pans of granite (20mm size).

(vi) Mixing was done manually as high efficiency could be achieved due to the small volume of concrete under consideration. The sand and cement were thoroughly dry-mixed before adding the granite. The mixing was done in six different parts though with same mix ratio.

(vii) The first part of the mix was mixed with distilled water (devoid of any impurity), to serve as the control. The other five (5) parts were mixed with water contaminated with $\mathrm{NaCl}$ in the following respective proportions of 100, 200,300, 400 and 500 $\mathrm{mg}$ of salt per litre of water.

(viii) Each of the parts was transported and placed into their respective moulds with hand-trowel (Plate 3) 
since the distance from mixing point was closer and the volume of concrete was equally not much. The moulds were placed on paved area to avoid contact with soil or ground. Adequate water was applied to ensure workability of the concrete. Three (6) cubes each were cast from each of the six (6) parts, making a total of thirty-six (36) cubes.

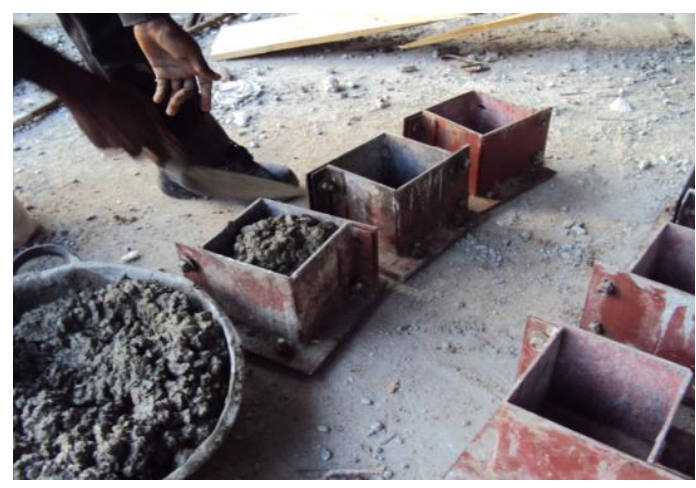

Plate 3: Casting of the concrete cubes

(ix) Compaction was carried out manually by gentle tapping with rod to allow even settlement of the fresh concrete in the moulds (Plate 4).

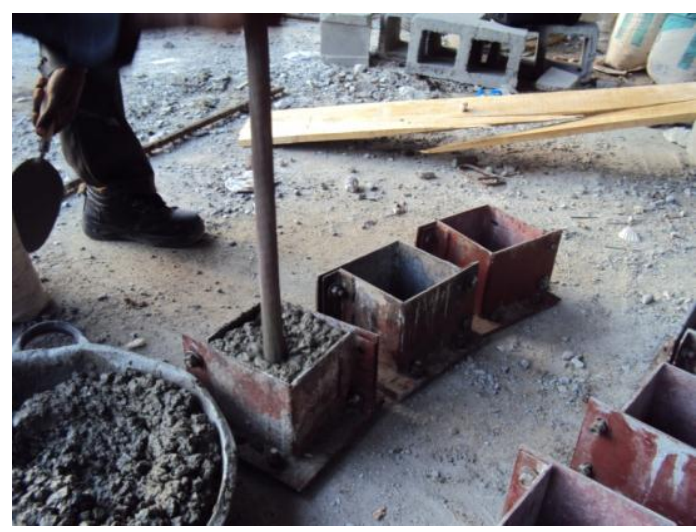

Plate 4: Compaction of fresh concrete with tapping rod

(x) The following day, the moulds were loosened from the concrete and its curing followed immediately by immersion in water baths (Plate 5).

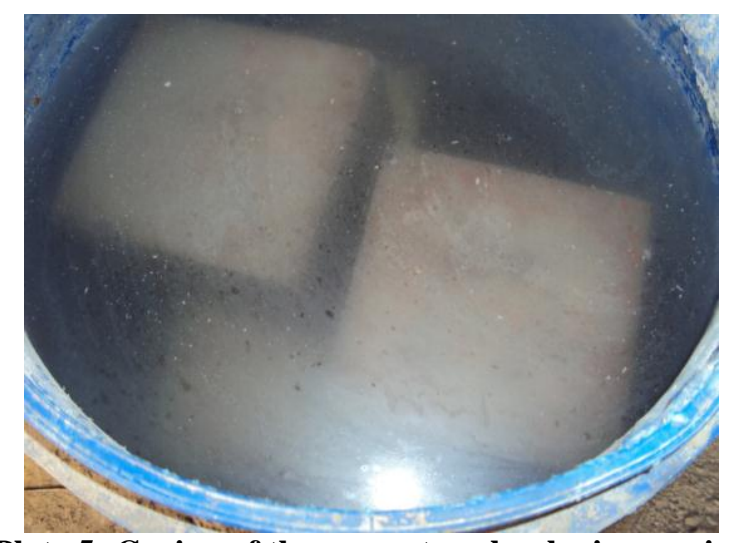

Plate 5: Curing of the concrete cubes by immersion

(xi) Compressive Strength test was carried out by crushing of the concrete cubes. Two (2) numbers from each part was carried out with the Compression Machine (Plate 6) in the laboratory at 7 days, 28 days and 56 days respectively after casting. This was to check the strength of concrete under the application of axial load. The parameters measured and recorded at every crushing day include cross sectional areas of the reinforced concrete, volume of the concrete, mass of the concrete, density of the concrete and maximum 
crushing load $(\mathrm{KN})$ from the machine. Compressive strength $\left(\mathrm{N} / \mathrm{mm}^{2}\right)$ was then calculated for each of the reinforced concrete.

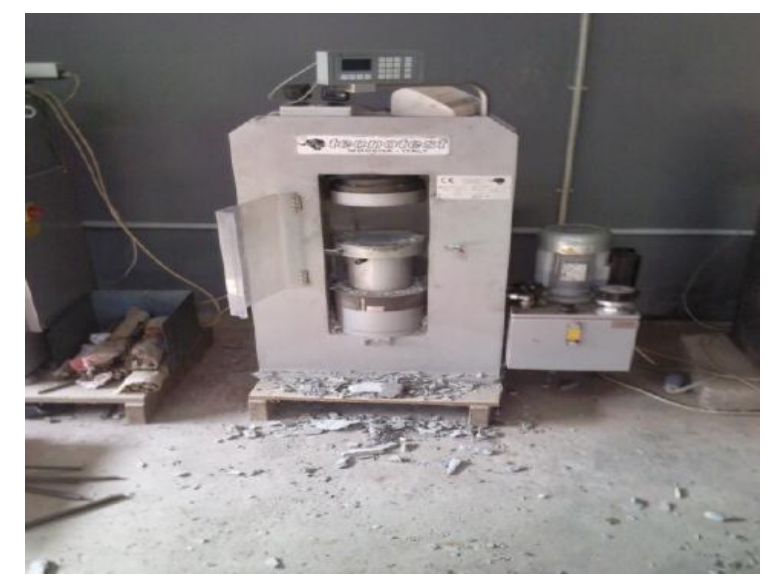

Plate 6: The Compressive Strength Machine

(xii) Separate results for each day of crushing were recorded for the control and the respective salt Concentrations.

\section{Results And Discussion}

The summaries of results are presented in tabular forms. Relevant calculations were made and the results discussed as follows:

\subsection{Results of Sieve Analysis}

The sieve analysis carried out on the soil sample is presented in the Table 2 below. It shows the percentage of the sample passing through different sieve sizes in dry sample.

Table 1: Sieve Analysis Results

\begin{tabular}{|c|c|c|c|c|c|}
\hline Sieve No & $\begin{array}{l}\text { Sieve diameter } \\
(\mathrm{cm})\end{array}$ & $\begin{array}{l}\text { Mass retained } \\
(\mathrm{g})\end{array}$ & $\%$ retained & $\begin{array}{c}\text { Cumulative \% } \\
\text { retained }\end{array}$ & $\%$ passing \\
\hline $5 / 6$ & 8.00 & 25.36 & 7.64 & 7.64 & 92.36 \\
\hline 5 & 4.00 & 74.42 & 21.89 & 29.62 & 70.38 \\
\hline 10 & 2.00 & 15.16 & 22.30 & 51.92 & 48.08 \\
\hline 18 & 1.00 & 54.10 & 15.98 & 67.90 & 33.10 \\
\hline 40 & 0.425 & 62.68 & 16.52 & 86.42 & 13.58 \\
\hline 60 & 0.250 & 21.85 & 6.45 & 92.87 & 7.13 \\
\hline 120 & 0.125 & 17.62 & 5.21 & 98.08 & 1.92 \\
\hline 200 & 0.075 & 6.50 & 1.92 & 100 & 0 \\
\hline
\end{tabular}

\subsection{Results of Specific Gravity test}

Specific gravity test is a test that determines the mass of equal volume of water of a given dry soil. The specification value of AASHTO for the soil in Africa is 2.60. It is used to know the behaviour quality of a soil. The results obtained are on Table 2 .

Table 2: Results of specific gravity

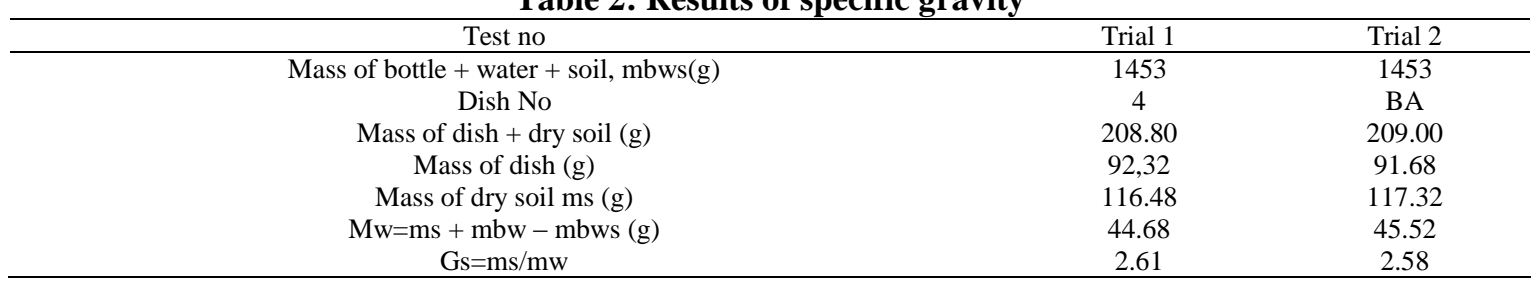

$\underline{\text { Larger Gs }}=\underline{2.61}=1.01<1.02$

Smaller Gs 2.58

Average Gs $=\frac{2.61+2.58}{2}=2.60$ 


\subsection{Results of Compressive Strength Test}

Compressive strength tests results show the varying results of the strength of the concrete with varying addition of respective salt concentration i.e $0,100,200,300,400$ and 500mg of contaminant per litre of water. The results are as shown in Tables $3-20$. Table 21 presents the summary of the compressive strengths. The graph in figure 7 depicts the trend.

(i) Compressive strength result at $0 \mathrm{mg} / \mathrm{ltr}$ of salt to water (the control)

Table 3: The Compressive Strength of $0 \mathrm{mg}$ / ltr. at 7 days

\section{CUBES}

\begin{tabular}{|c|c|c|c|c|}
\hline \multicolumn{2}{|r|}{$\mathrm{S} / \mathrm{N}$} & & & \\
\hline 1 & Dimensions (mm) & \multicolumn{3}{|c|}{$150 X 150 X 150$} \\
\hline 2 & Weight (gms) & 8260 & 8210 & 0 \\
\hline 3 & Volume $\left(\mathrm{cm}^{3}\right)$ & 3375 & 3375 & 3375 \\
\hline 4 & Density $\left(\mathrm{gm} / \mathrm{cm}^{2}\right)$ & 2.45 & 2.43 & 0.00 \\
\hline 5 & Cross-sectional Area $\left(\mathrm{mm}^{2}\right)$ & 22.5 & 22.5 & 22.5 \\
\hline 6 & Maximum Load (KN) & 490 & 450 & 0 \\
\hline 7 & Compressive Strength $\left(\mathrm{N} / \mathrm{mm}^{2}\right)$ & 21.78 & 20.00 & 0.00 \\
\hline 8 & Average Strength $\left(\mathrm{N} / \mathrm{mm}^{2}\right)$ & & 20.89 & \\
\hline
\end{tabular}

Table 4: The Compressive Strength of $0 \mathrm{mg} / \mathrm{ltr}$. at 28 days (the control) CUBES

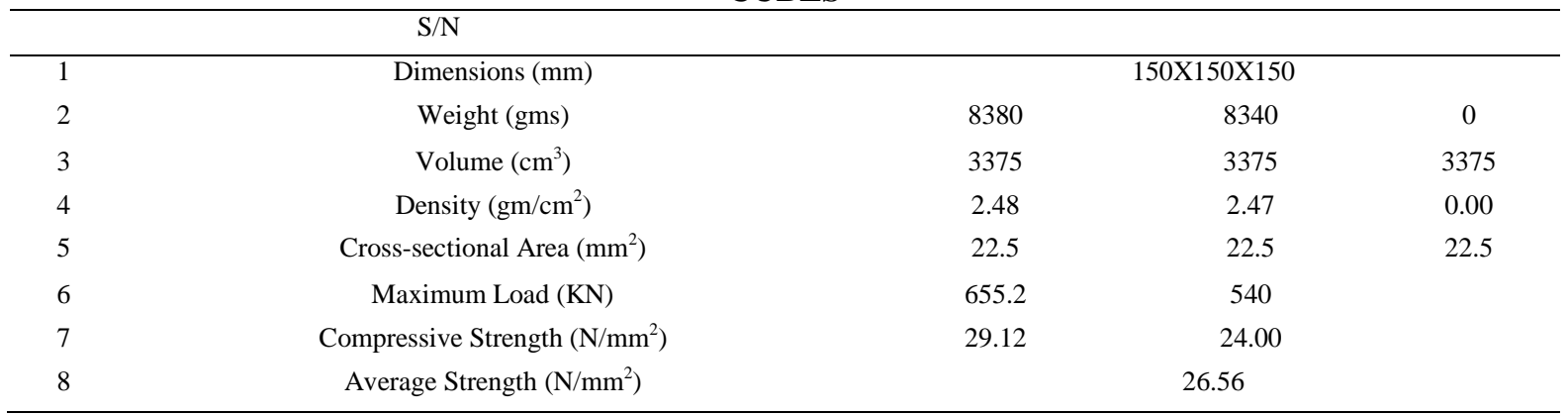

Table 5: The Compressive Strength of 0mg / ltr. at 56 days (the control) CUBES

\begin{tabular}{lccc}
\hline \multicolumn{1}{c}{ S/N } & & \\
\hline 1 & Dimensions $(\mathrm{mm})$ & 13230 & 150 X150X150 \\
2 & Weight $(\mathrm{gms})$ & 3375 & 13432.5 \\
3 & Volume $\left(\mathrm{cm}^{3}\right)$ & 3.92 & 3375 \\
4 & Density $\left(\mathrm{gm} / \mathrm{cm}^{2}\right)$ & 22.5 & 3.98 \\
5 & Cross-sectional Area $\left(\mathrm{mm}^{2}\right)$ & 819.45 & 22.5 \\
6 & Maximum Load $(\mathrm{KN})$ & 36.42 & 850.95 \\
7 & Compressive Strength $\left(\mathrm{N} / \mathrm{mm}^{2}\right)$ & 37.82 \\
8 & Average Strength $\left(\mathrm{N} / \mathrm{mm}^{2}\right)$ & 37.12 & 22.5 \\
\hline
\end{tabular}

(ii) Compressive strength result at $100 \mathrm{mg} / \mathrm{ltr}$ of salt to water

Table 6: The Compressive Strength of $100 \mathrm{mg}$ / ltr. at 7 days

\begin{tabular}{lccc} 
& CUBES & & \\
\hline & & & \\
\hline 1 & S/N & 8260 & $150 \times 150 \times 150$ \\
2 & Dimensions $(\mathrm{mm})$ & 3375 & 8200 \\
3 & Weight $(\mathrm{gms})$ & 2.45 & 3375 \\
4 & Volume $\left(\mathrm{cm}^{3}\right)$ & 22.5 & 2.43 \\
5 & Density $\left(\mathrm{gm} / \mathrm{cm}^{2}\right)$ & 489.15 & 22.5 \\
6 & Cross-sectional Area $\left(\mathrm{mm}^{2}\right)$ & 21.74 & 450.45 \\
7 & Maximum Load $(\mathrm{KN})$ & 22.5 & 20.02 \\
8 & Compressive Strength $\left(\mathrm{N} / \mathrm{mm}^{2}\right)$ & & 20.88 \\
\hline
\end{tabular}


Table 7: The Compressive Strength of 100mg / ltr. at 28 days CUBES

\begin{tabular}{lccc}
\hline \multicolumn{1}{c}{ S/N } & & \\
\hline 1 & Dimensions $(\mathrm{mm})$ & 8382 & 150 X150X150 \\
2 & Weight $(\mathrm{gms})$ & 3375 & 8335 \\
3 & Volume $\left(\mathrm{cm}^{3}\right)$ & 2.48 & 3375 \\
4 & Density $\left(\mathrm{gm} / \mathrm{cm}^{2}\right)$ & 22.5 & 2.47 \\
5 & Cross-sectional Area $\left(\mathrm{mm}^{2}\right)$ & 529.88 & 22.5 \\
6 & Maximum Load $(\mathrm{KN})$ & 23.55 & 640.13 \\
7 & Compressive Strength $\left(\mathrm{N} / \mathrm{mm}^{2}\right)$ & 28.45 \\
8 & Average Strength $\left(\mathrm{N} / \mathrm{mm}^{2}\right)$ & 26.00 & \\
\hline
\end{tabular}

Table 8: The Compressive Strength of 100mg / Itr. at 56 days CUBES

\begin{tabular}{lccc}
\hline \multicolumn{1}{c}{ S/N } & & \\
\hline 1 & Dimensions $(\mathrm{mm})$ & 8438 & 150 X150X150 \\
2 & Weight $(\mathrm{gms})$ & 3375 & 8269 \\
3 & Volume $\left(\mathrm{cm}^{3}\right)$ & 2.50 & 3375 \\
4 & Density $\left(\mathrm{gm} / \mathrm{cm}^{2}\right)$ & 22.5 & 2.45 \\
5 & Cross-sectional Area $\left(\mathrm{mm}^{2}\right)$ & 790.2 & 22.5 \\
6 & Maximum Load $(\mathrm{KN})$ & 3375 & 881.55 \\
7 & Compressive Strength $\left(\mathrm{N} / \mathrm{mm}^{2}\right)$ & 39.18 \\
8 & Average Strength $\left(\mathrm{N} / \mathrm{mm}^{2}\right)$ & & 37.15 \\
\hline
\end{tabular}

(iii) Compressive strength result at $200 \mathrm{mg} / \mathrm{ltr}$ of salt to water

Table 9: The Compressive Strength of 200mg / ltr. at 7 days CUBES

\begin{tabular}{|c|c|c|c|c|}
\hline \multicolumn{2}{|r|}{$\mathrm{S} / \mathrm{N}$} & & & \\
\hline 1 & Dimensions (mm) & \multicolumn{3}{|c|}{$150 \times 150 \times 150$} \\
\hline 2 & Weight (gms) & 8300 & 8320 & \\
\hline 3 & Volume $\left(\mathrm{cm}^{3}\right)$ & 3375 & 3375 & 3375 \\
\hline 4 & Density $\left(\mathrm{gm} / \mathrm{cm}^{2}\right)$ & 2.46 & 2.47 & \\
\hline 5 & Cross-sectional Area $\left(\mathrm{mm}^{2}\right)$ & 22.5 & 22.5 & 22.5 \\
\hline 6 & Maximum Load $(\mathrm{KN})$ & 551.7 & 573.3 & \\
\hline 7 & Compressive Strength $\left(\mathrm{N} / \mathrm{mm}^{2}\right)$ & 24.52 & 25.48 & \\
\hline 8 & Average Strength $\left(\mathrm{N} / \mathrm{mm}^{2}\right)$ & & 25.00 & \\
\hline
\end{tabular}

Table 10: The Compressive Strength of $200 \mathrm{~g} / \mathrm{ltr}$. at 28 days CUBES

\begin{tabular}{lccc}
\hline \multicolumn{1}{c}{ S/N } & & \\
\hline 1 & Dimensions $(\mathrm{mm})$ & 8573 & 150 X150X150 \\
2 & Weight $(\mathrm{gms})$ & 3375 & 7796 \\
3 & Volume $\left(\mathrm{cm}^{3}\right)$ & 2.54 & 3375 \\
4 & Density $\left(\mathrm{gm} / \mathrm{cm}^{2}\right)$ & 22.5 & 2.31 \\
5 & Cross-sectional Area $\left(\mathrm{mm}^{2}\right)$ & 567 & 22.5 \\
6 & Maximum Load $(\mathrm{KN})$ & 25.20 & 543.6 \\
7 & Compressive Strength $\left(\mathrm{N} / \mathrm{mm}^{2}\right)$ & 24.16 \\
8 & Average Strength $\left(\mathrm{N} / \mathrm{mm}^{2}\right)$ & & 24.68 \\
\hline
\end{tabular}

Table 11: The Compressive Strength of 200mg / ltr. at 56 days CUBES

\begin{tabular}{lccc}
\hline \multicolumn{1}{c}{ S/N } & & \\
\hline 1 & Dimensions $(\mathrm{mm})$ & 8490 & 150 X150X150 \\
2 & Weight $(\mathrm{gms})$ & 3375 & 8550 \\
3 & Volume $\left(\mathrm{cm}^{3}\right)$ & 2.52 & 3375 \\
4 & Density $\left(\mathrm{gm} / \mathrm{cm}^{2}\right)$ & 22.5 & 2.53 \\
5 & Cross-sectional Area $\left(\mathrm{mm}^{2}\right)$ & 477 & 22.5 \\
6 & Maximum Load $(\mathrm{KN})$ & 21.20 & 558 \\
7 & Compressive Strength $\left(\mathrm{N} / \mathrm{mm}^{2}\right)$ & 24.80 \\
8 & Average Strength $\left(\mathrm{N} / \mathrm{mm}^{2}\right)$ & 23.00 \\
\hline
\end{tabular}

(iv) Compressive strength result at $300 \mathrm{mg} / \mathrm{ltr}$ of salt to water 
Table 12: The Compressive Strength of 300mg / ltr. at 7 days

\section{CUBES}

\begin{tabular}{lccc}
\hline \multicolumn{1}{c}{ S/N } & & \\
\hline 1 & Dimensions $(\mathrm{mm})$ & 8370 & 150 X150X150 \\
2 & Weight $(\mathrm{gms})$ & 3375 & 8350 \\
3 & Volume $\left(\mathrm{cm}^{3}\right)$ & 2.48 & 3375 \\
4 & Density $\left(\mathrm{gm} / \mathrm{cm}^{2}\right)$ & 22.5 & 2.47 \\
5 & Cross-sectional Area $\left(\mathrm{mm}^{2}\right)$ & 554 & 22.5 \\
6 & Maximum Load $(\mathrm{KN})$ & 24.60 & 608 \\
7 & Compressive Strength $\left(\mathrm{N} / \mathrm{mm}^{2}\right)$ & 27.00 \\
8 & Average Strength $\left(\mathrm{N} / \mathrm{mm}^{2}\right)$ & 25.80 & \\
\hline
\end{tabular}

Table 13: The Compressive Strength of 300mg / ltr. at 28 days

CUBES

\begin{tabular}{lccc}
\hline \multicolumn{1}{c}{ S/N } & & \\
\hline 1 & Dimensions $(\mathrm{mm})$ & 8290 & 150 X150X150 \\
2 & Weight $(\mathrm{gms})$ & 3375 & 8284 \\
3 & Volume $\left(\mathrm{cm}^{3}\right)$ & 2.46 & 3375 \\
4 & Density $\left(\mathrm{gm} / \mathrm{cm}^{2}\right)$ & 22.5 & 2.45 \\
5 & Cross-sectional Area $\left(\mathrm{mm}^{2}\right)$ & 540 & 22.5 \\
6 & Maximum Load $(\mathrm{KN})$ & 24.00 & 538 \\
7 & Compressive Strength $\left(\mathrm{N} / \mathrm{mm}^{2}\right)$ & 23.90 \\
8 & Average Strength $\left(\mathrm{N} / \mathrm{mm}^{2}\right)$ & 23.95 & \\
\hline
\end{tabular}

Table 14: The Compressive Strength of 300mg / ltr. at 56 days

\section{CUBES}

\begin{tabular}{lccc}
\hline \multicolumn{1}{c}{ S/N } & & \\
\hline 1 & Dimensions $(\mathrm{mm})$ & 8573 & 150 X150X150 \\
2 & Weight $(\mathrm{gms})$ & 3375 & 7796 \\
3 & Volume $\left(\mathrm{cm}^{3}\right)$ & 2.54 & 3375 \\
4 & Density $\left(\mathrm{gm} / \mathrm{cm}^{2}\right)$ & 22.5 & 2.31 \\
5 & Cross-sectional Area $\left(\mathrm{mm}^{2}\right)$ & 567 & 22.5 \\
6 & Maximum Load $(\mathrm{KN})$ & 25.20 & 544 \\
7 & Compressive Strength $\left(\mathrm{N} / \mathrm{mm}^{2}\right)$ & 24.16 \\
8 & Average Strength $\left(\mathrm{N} / \mathrm{mm}^{2}\right)$ & & 24.68 \\
\hline
\end{tabular}

(v) Compressive strength result at $400 \mathrm{mg} / \mathrm{ltr}$ of salt to water

Table 15: The Compressive Strength of 400mg / ltr. at 7 days CUBES

\begin{tabular}{|c|c|c|c|c|}
\hline \multicolumn{5}{|c|}{$\mathrm{S} / \mathrm{N}$} \\
\hline 1 & Dimensions (mm) & & $\mathrm{X} 150 \mathrm{X} 150$ & \\
\hline 2 & Weight (gms) & 8540 & 8580 & \\
\hline 3 & Volume $\left(\mathrm{cm}^{3}\right)$ & 3375 & 3375 & 3375 \\
\hline 4 & Density $\left(\mathrm{gm} / \mathrm{cm}^{2}\right)$ & 2.53 & 2.54 & \\
\hline 5 & Cross-sectional Area $\left(\mathrm{mm}^{2}\right)$ & 22.5 & 22.5 & 22.5 \\
\hline 6 & Maximum Load (KN) & 885 & 900 & \\
\hline 7 & Compressive Strength $\left(\mathrm{N} / \mathrm{mm}^{2}\right)$ & 39.33 & 40.00 & \\
\hline 8 & Average Strength $\left(\mathrm{N} / \mathrm{mm}^{2}\right)$ & & 39.67 & \\
\hline
\end{tabular}

Table 16: The Compressive Strength of 400mg / ltr. at 28 days CUBES

\begin{tabular}{lccc}
\hline \multicolumn{3}{c}{ CUBES } \\
\hline 1 & S/N & & \\
2 & Dimensions $(\mathrm{mm})$ & 8390 & $150 \times 150 X 150$ \\
3 & Weight $(\mathrm{gms})$ & 3375 & 8365 \\
4 & Volume $\left(\mathrm{cm}^{3}\right)$ & 2.49 & 3375 \\
5 & Density $\left(\mathrm{gm} / \mathrm{cm}^{2}\right)$ & 22.5 & 2.48 \\
6 & Cross-sectional Area $\left(\mathrm{mm}^{2}\right)$ & 680 & 22.5 \\
7 & Maximum Load $(\mathrm{KN})$ & 30.22 & 690 \\
8 & Compressive Strength $\left(\mathrm{N} / \mathrm{mm}^{2}\right)$ & 30.68 & 30.45 \\
\hline
\end{tabular}


Table 17: The Compressive Strength of 400mg / ltr. at 56 days CUBES

\begin{tabular}{lccc}
\hline & S/N & & \\
\hline 1 & Dimensions $(\mathrm{mm})$ & 8285 & $150 \times 150 \times 150$ \\
2 & Weight $(\mathrm{gms})$ & 3375 & 8290 \\
3 & Volume $\left(\mathrm{cm}^{3}\right)$ & 2.45 & 3375 \\
4 & Density $\left(\mathrm{gm} / \mathrm{cm}^{2}\right)$ & 22.5 & 2.46 \\
5 & Cross-sectional Area $\left(\mathrm{mm}^{2}\right)$ & 545 & 22.5 \\
6 & Maximum Load $(\mathrm{KN})$ & 24.20 & 558 \\
7 & Compressive Strength $\left(\mathrm{N} / \mathrm{mm}^{2}\right)$ & 24.80 \\
8 & Average Strength $\left(\mathrm{N} / \mathrm{mm}^{2}\right)$ & & 24.50 \\
\hline
\end{tabular}

(vi) Compressive strength result at $500 \mathrm{mg} / \mathrm{ltr}$ of salt to water

Table 18: The Compressive Strength of 500mg / ltr. at 7 days CUBES

\begin{tabular}{lcrr}
\hline \multicolumn{1}{c}{ CUBES } \\
\hline 1 & S/N & & \\
2 & Dimensions $(\mathrm{mm})$ & 8450 & $150 \times 150 X 150$ \\
3 & Weight $(\mathrm{gms})$ & 3375 & 8510 \\
4 & Volume $\left(\mathrm{cm}^{3}\right)$ & 2.50 & 3375 \\
5 & Density $\left(\mathrm{gm} / \mathrm{cm}^{2}\right)$ & 22.5 & 2.52 \\
6 & Cross-sectional Area $\left(\mathrm{mm}^{2}\right)$ & 900 & 22.5 \\
7 & Maximum Load $(\mathrm{KN})$ & 40.00 & 893.25 \\
8 & Compressive Strength $\left(\mathrm{N} / \mathrm{mm}^{2}\right)$ & 39.70 & 39.85 \\
\hline
\end{tabular}

Table 19: The Compressive Strength of 500mg / ltr. at 28 days

\begin{tabular}{|c|c|c|c|c|}
\hline \multicolumn{5}{|c|}{ CUBES } \\
\hline 1 & Dimensions (mm) & & $\mathrm{X} 150 \mathrm{X} 150$ & \\
\hline 2 & Weight (gms) & 8390 & 8365 & \\
\hline 3 & Volume $\left(\mathrm{cm}^{3}\right)$ & 3375 & 3375 & 3375 \\
\hline 4 & Density $\left(\mathrm{gm} / \mathrm{cm}^{2}\right)$ & 2.49 & 2.48 & \\
\hline 5 & Cross-sectional Area $\left(\mathrm{mm}^{2}\right)$ & 22.5 & 22.5 & 22.5 \\
\hline 6 & Maximum Load $(\mathrm{KN})$ & 680 & 690 & \\
\hline 7 & Compressive Strength $\left(\mathrm{N} / \mathrm{mm}^{2}\right)$ & 30.22 & 30.68 & \\
\hline 8 & Average Strength $\left(\mathrm{N} / \mathrm{mm}^{2}\right)$ & & 30.49 & \\
\hline
\end{tabular}

Table 20: The Compressive Strength of 500mg / ltr. at 56 days CUBES

\begin{tabular}{lccc}
\hline \multicolumn{1}{c}{ S/N } & & \\
\hline 1 & Dimensions $(\mathrm{mm})$ & 8285 & 150 X150X150 \\
2 & Weight $(\mathrm{gms})$ & 3375 & 8290 \\
3 & Volume $\left(\mathrm{cm}^{3}\right)$ & 2.45 & 3375 \\
4 & Density $\left(\mathrm{gm} / \mathrm{cm}^{2}\right)$ & 22.5 & 2.46 \\
5 & Cross-sectional Area $\left(\mathrm{mm}^{2}\right)$ & 545 & 22.5 \\
6 & Maximum Load $(\mathrm{KN})$ & 24.20 & 550 \\
7 & Compressive Strength $\left(\mathrm{N} / \mathrm{mm}^{2}\right)$ & 24.80 \\
8 & Average Strength $\left(\mathrm{N} / \mathrm{mm}^{2}\right)$ & 24.30 & \\
\hline
\end{tabular}

Table 21: Summary of the Compressive Strengths

\begin{tabular}{|c|c|c|c|}
\hline \multirow{2}{*}{$\begin{array}{c}\text { Contaminant's } \\
\text { concentration } \\
(\boldsymbol{m} \text { /l } \text { of } \text { water })\end{array}$} & Day 7 & Compressive Strength after specified days $\left(\mathbf{N} / \mathbf{m m}^{\mathbf{2}}\right)$ \\
\cline { 2 - 4 } & & & Day 28 56 \\
\hline 0 & 20.89 & 26.56 & 37.12 \\
\hline 100 & 20.88 & 26.00 & 37.15 \\
\hline 200 & 25.00 & 24.68 & 23.00 \\
\hline 300 & 25.80 & 23.95 & 24.68 \\
\hline 400 & 39.67 & 30.45 & 24.50 \\
\hline 500 & 39.85 & 30.49 & 24.30 \\
\hline
\end{tabular}




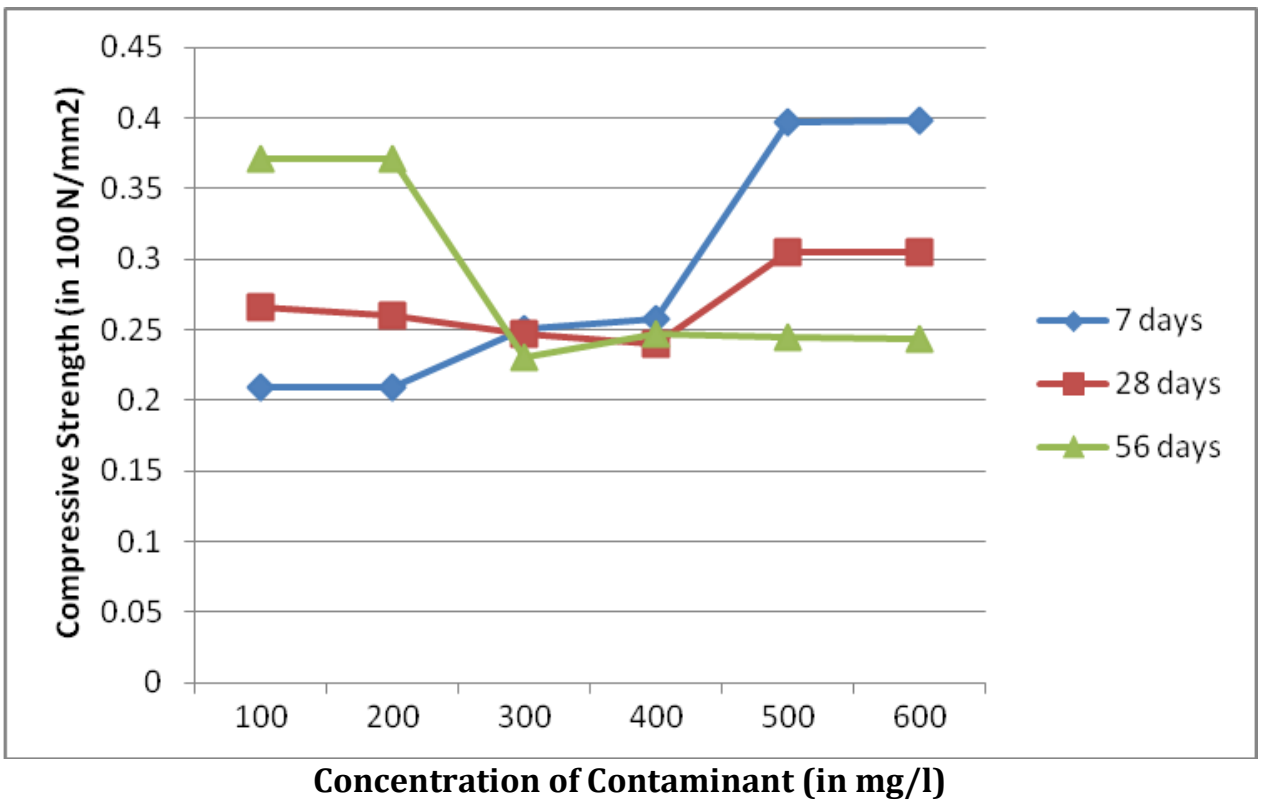

Fig. 1: The trend of compressive strengths of the concrete with age as contamination level increases

The sieve analysis test result shows that the soil sample is sandy (fine aggregate) with very little percentage of small stones. As experimented over the years, that African soil (sand) should have specific gravity not lesser than 2.60 which is what the outcome of the result is. Compressive strength tests that were carried out had varying indicative result as the salt concentration varies respectively. Compressive strength results as summarized on Table XXI shows that the chloride salt does not have appreciable effect on the concrete in the earlier age (up to 28 days), its negative effects were noticeable the more in the 56 day strength when there is a sharp decline from 37.12 to $24.30 \mathrm{~N} / \mathrm{mm}^{2}$. The graph in Figure 1 corroborates this fact as well giving the 56 day strength of the strongest contamination as the weakest. It was generally observed that the higher the concentration of the contaminant and with increase in age the lower the compressive strengths recorded. Also, it was noted that the fresh concrete with higher salt concentration have elongated setting -times. This implies that higher salt contents delay the setting time of concrete. The initial setting time was observed to exceed 50 minutes while final setting time was beyond 12 hours after placing in the moulds.

\section{Conclusions}

The study therefore concludes that the contamination effects of chloride salt on the compressive strength of concrete worsen with concrete age and thus should be prevented at all cost. The initial retardation in setting times of the concrete mixed with chloride contaminated water is equally undesirable. The use of clean water free of impurities is hereby recommended for concrete mixes.

\section{References}

[1] Oyenuga, V., 'Reinforced Concrete Design'. ASROS Ltd, 2005, pp 4-6.

[2] Wikipedia, 'Salt water and concrete', 2005.

[3] Taylor, H.F.W 'Chemistry of Cements' Vol. 1 Academic Press UK and USA, 1964.

[4] British Standard, 'Seawater and Concrete', 1970.

[5] Neville A.M. and Brooks J.J., 'Concrete Technology'. $2^{\text {nd }}$ Edition, 1997, pp 54.

[6] American Institute of Concrete, 'International Conference on Effect of Chloride on water in Concreting', Collorado, U.S.A., 2009.

[7] Shetty, M.S., 'Concrete Technology: Theory and practice'. S. Chand \& Company Ltd, 2000, pp 28, 67, 119 and 230.

[8] Falade F. 'International Conference on Structural Engineering Analysis and Modeling'. SEAM3. Kwame Nkruma University of Science and Technology, Ghana, 1997.

[9] Valore R.C 'Insulating Concrete', ACI Journal, Vol 5, Nov. 1956.

[10] Waddell, J.J 'Concrete Construction Hand Book'. McGraw Hill, 1968.

[11] S.O. Ojoawo and A.M Oladejo (2013) An investigation into the effects of contaminated with chloride salts on the compressive strength of concrete. Proceedings of 2nd International Conference on Engineering and Technology Research, FET Conference 2013, LAUTECH, Ogbomoso, Nigeria (March 2013), 2: 1-10. ISBN: 978-2902-58-6. 